\title{
PELATIHAN DESAIN PRODUK DAN TEKNOLOGI INDUSTRI KERAJINAN ANYAMAN ECENG GONDOK
}

\author{
Daud Elias Pangkey \\ Fakultas Bahasa dan Seni, Universitas Negeri Manado
}

\begin{abstract}
Pengabdian masyarakat ini sesungguhnya berorientasi pada upaya memberdayakan kelompok masyarakat pengrajin, khususnya dalam pengembangan desain produk yang sesuai kebutuhan pasar/ konsumen dengan tetap memperhatikan kualitas produk melalui pendekatan teknologi industri. Dengan demikian diharapkan ada peningkatan taraf ekonomi/ kesejahteraan masyarakat pengrajin di pedesaan melalui pendekatan IPTEKS, sesuai amanat Tridarma Perguruan Tinggi. Untuk mencapai tujuan tersebut ditempuh melalui metode pembelajaran andragogik yang lebih menekankan pada pelatihan teknis (praktek), mulaidari keterampilan desain produk, teknis produksi secara industrial sampai pada sistem manajemen pemasaran produk. Program pengabdian masyarakat ini telah membantu para pengrajin baik dalampengadaan bahan bakuanyaman beserta asesorisnya maupun sejumlah peralatan penunjang teknologi produksi/ industri, sehingga desain produk yang ditawarkan dapat terwujud sesuai harapan, berkualitas dan berciri khas serta dapat bersaing di pasaran.

Target yang telah dilaksanakan melalui program ini meliputi : (1) pengadaan bahan baku berupa tangkai eceng gondok, kain pelapis, rets, tali/ sabut gantungan, pita-pita dan asesoris penunjang keindahan produk anyaman, (2) pengadaan peralatan, mesin jahit dll, (3) prosespengolahan bahan, pengenalan desain produk sampai pada proses produksi anyaman beragam desain produk berupa tas, dompet dsj yang modis serta trendy (seperti yang tampak pada dokumen fisual berupa foto-foto terlampir).
\end{abstract}

Keywords: Desain Produk, Teknologi Industri, Kerajinan Anyaman. 


\section{PENDAHULUAN}

Krisis ekonomi merupakan hal yang paling mendasar ditengah krisis multifimensional yang sedang melanda bangsa dan negara Indonesia. Karenanya pemerintah dalam mengatasinya menempuh beragam upaya meningkatkan taraf ekonomi/ kesejahteraan masyarakat. Salah satu program popular sebagai bentuk kepedulian social pemerintah adalah pengembangan "Ekonomi Kerakyatan (Ekonomi Kreatif)" yang berorientasi pada upaya pemberdayaan serta pembinaan bagi usaha - usaha kecil yang hanya mengandalkan keterampilan tanpa modal yang berarti dengan bahan baku yang mudah diperoleh dan disajikan/ sesuai potensi di lingkungan masyarakat sekitar, baik itu berupa usaha kuliner, konveksi-tekstil dsj, maupun keterampilan kerajinan berupa seni kriya yang umumnya tumbuh dan hidup di kalangan masyarakat pedesaan/ pinggiran kota.

Salah satu lembaga tinggi negara yang telah turut berperan dalam akselerasi terwujudnya suatu masyarakat yang berbudaya, maju, berkualitas sejahtera dan berdaya saing adalah Kementrian Riset Teknologi dan Pendidikan Tinggi melalui Dirjen Penelitian dan Pengabdian Masyarakat. Bentuk Kepedulian Sosial DIRJEN Penelitian dan Pengabdian Masyarakat ini dijabarkan melalui program pro rakyat setiap Lembaga Perguruan Tinggi dengan menyisikan dana PNBP untuk pengabdian masyarakat, yang berorientasi pada penerapan Ilmu Pengetahuan, Teknologi dan Seni (IPTEKS) masuk desa/ kelurahan demi menjawab kebutuhan masyarakat menurut karakter permasalahan/ tantangan masingmasing.

Upaya pemberdayaan masyarakat pengrajin anyaman eceng gondok melalui pelatihan/ pembekalan IPTEKS ini bertujuan meningkatkan ketrampilan dan profesionalitas pekerjaan yang ditekuni secara tradisional ketaraf industrial demi kualitas dan produktifitas yang secara otomatis meningkatkan nilai jual produk yang berdampak pada peningkatan taraf ekonomi/ kesejahteraan. Dipihak lain membantu pemerintah dalam mengatasi dan menanggulangi permasalahan eceng gondok yang semakin menyebar dipermukaan Danau Tondano dan merusak sistem ekosistem serta potensi sumber daya hayati yang selama ini mendukung/ menyangga perekonomian masyarakat pesisir danau (mengatasi masaalah melalui pemberdayaan masaalah dan mas yarakat sekitar masaalah).

Program penelitian ini benar-benar sangat membantu dan memotivasi kelompok pengrajin anyaman eceng gondok tradisional di Desa Watumea. Pengadaan bahan baku dan sejumlah peralatan pendukung proses teknologi/ industrialisasi pekerjaan, semakin menggairahkan/ meningkatkan produktivitas dan profesionalitas para pengrajin yang siap memproduksi beragam desain produk anyaman benda fungsional berupa tas dan dompet yang modis-trendy baik untuk konsusi masyarakat sekitar (lokal) maupun sebagai benda-benda cendra mata para wisatawan.

Dibalik gairah dan motivasi yang terbangun dari program pelatihan keterampilan pendekatan IPTEKS ini, permasalahan klasik yang menjadi kendala masyarakat pengrajin yang umumnya hidup di pedesaan antara lain kendala modal usaha keberlanjutan, sehingga para pengrajin hanya menjadikan pekerjaan ini sebagai usaha sampingan selain berkebun/ bertani. Dilain pihak lain pemerintah/ instansi terkait belum optimal dalam upaya pembinaan dan pemberdayaannya masyarakat pengrajin yang seyogyanya dapat dijadikan ujung tombak dan basis pengembangan ekonomi kreatif.

Karenanya pelaksana program pengabdian masyarakat ini turut berupaya untuk meyakinkan pemerintah setempat/ instansi terkait untuk dapat menjadikan kelompok pengrajin ini sebagai aset sentra industri kerajinan andalan yang dapat meningkatkan ekonomi pengrajin yang turut menggenjot peningkatan Pendapatan Asli Daerah (PAD) dan menunjang sektor pariwisata budaya daerah setempat melalui usaha/ industry kreatif yang hidup dilingkungan masyarakat pedesaan (masyarakat pinggiran kota) berupa produk cendra mata.

\section{METODE}

\section{Materi}

Materi yang diberikan meliputi :

- Pengetahuan pengantar sebagai upaya motivasi dan inovasi dalam pemberdayaan masyarakat pengrajin anyaman media eceng gondok. Diperkaya spirit kewiraswastaan, profesionalitas, produktifitas serta sistem industrial demi peningkatan taraf hidup/ perekonomian masyarakat 
- Pelatihan desain produk dan teknologi sebagai upaya industrialisasi pengrajin anyaman eceng gondok dengan beragam jenis produk benda-benda fungsional maupun asesoris baik sebagai konsumsi

\begin{tabular}{|c|c|c|c|c|c|c|}
\hline No & Jenis & & $\overline{\mathrm{Wak}}$ & & & Keterangan \\
\hline & Kegiatan & \begin{tabular}{l|l}
1 & 2
\end{tabular} & 3 & 4 & 5 & \\
\hline 1. & $\begin{array}{l}\text { Persiapan } \\
\text { dengan } \\
\text { Kelompok } \\
\text { mitra }\end{array}$ & & & & & $\begin{array}{l}\text { Berkoordinasi } \\
\text { dengan pemerintah } \\
\text { desa dan kelompok } \\
\text { mitra }\end{array}$ \\
\hline 2. & $\begin{array}{l}\text { Pelaksanaan } \\
\text { pelatihan } \\
\text { keterampila } \\
\text { n eceng } \\
\text { gondok } \\
\text { dengan } \\
\text { masyarakat } \\
\text { mitra } \\
\text { (pengrajin) }\end{array}$ & & & & & $\begin{array}{lr}\text { Penyajian remua } \\
\text { materi pelatihan } \\
\text { yang diikuti secara } \\
\text { optimal oleh } \\
\text { kelompok pengrajin }\end{array}$ \\
\hline 3. & $\begin{array}{l}\text { Pemantauan } \\
\text { dan evaluasi }\end{array}$ & & & & & $\begin{array}{l}\text { Pendampingan } \\
\text { teknis produksi/ } \\
\text { evaluasi mutu dan } \\
\text { pemasaran }\end{array}$ \\
\hline 4. & $\begin{array}{l}\text { Penyusunan } \\
\text { laporan }\end{array}$ & & & & & $\begin{array}{l}\text { Berdasarkan data } \\
\text { selama proses } \\
\text { pelaksanaan } \\
\text { pelatihan dan hasil } \\
\text { evaluasi }\end{array}$ \\
\hline & $\begin{array}{l}\text { Pemasukan } \\
\text { laporan }\end{array}$ & & & & & Tindak lanjut \\
\hline
\end{tabular}

lokal maupun konsumsi wisata (cendramata)

- Pengenalan serta pelatihan teknologi industrial dalam proses pengolahan bahan dengan bantuan perangkat peralatan yang bersifat mekanik sehingga produktivitas dan profesionalitas serta kualitas produk kerajinan memenuhi kebutuhan dan dapat bersaing dipasaran umum.

Untuk mendukung upaya industrialisasi tersebut dibutuhkan bahan-bahan dan peralatan sebagai berikut :

\section{a.1. Bahan Baku Anyaman}

- Eceng Gondok

- Rotan olahan

- Papan

\section{a.2. Bahan Pendukung}

- Zat perekat

- Sabut untuk tas/ dompet

- Kain satin

- Benang nilon

- Zat pewarna

- Retsleting

- Zat pelapis (politur air)

- Asesoris pelengkap

- Pita perekat

b. Peralatan :
- Mesin jahit

- Cuter

- Alat pemipih

- Mata Cuter

- Pistol lem listrik

- Jarum sulam

- Wadah perebusan

- Gunting kertas

- Gergaji

- Sekop

\section{Metode}

a. Metode Ceramah : Sebagai pengantar materi dalam upaya memberikan kesadaran akan pentingnya IPTEKS bagi pengrajin sekaligus memberdayakan melalui pengembangan desain, teknologi dan industrialisasi kerajinan anyaman eceng gondok.

b. Pelatihan : Bimbingan praktis tentang inovasi desain, proses teknologi dan industrialisasi usaha produksi.

c. Pendampingan : Pasca pelatihan ditindaklanjuti pendampingan teknis dalam proses produksi di basis kelompok usaha bersama (KUB) dan manajemen pemasaran. Rancangan Kegiatan

Proses evaluasi meliputi penguasaan 5 komponen kompetensi yang dipersyarati seorang pengrajin anyaman eceng gondok yang professional, produktif, berkualitas dan industrial yaitu : keterampilan mengolah bahan baku, penguasaan/ penerapan desain, keterampilan teknik berproduksi, kreativitas serta finising. Semua diberi skor baik perorangan maupun keseluruhan diberi nilai rata - rata keberhasilan.

\section{HASIL DAN PEMB AHASAN \\ Hasil}

Dari hasil pelatihan semua peserta berhasil menguasai teknologi dan desain produk sebagai upaya industrialisasi yang dibuktikan dengan hasil karya selama pelatihan dengan produk : benda fungsional berupa ikan kolekan sebagai variasi tempat alat tulis meja kantor, tempat kartu nama, tempat tisu dan alat tulis kantor dan beberapa asesoris lainnya.

Indikator keberhasilan penguasaan keterampilan sebagai upaya industrialisasi kerajinan tempurung kelapa dapat pada table berikut : 


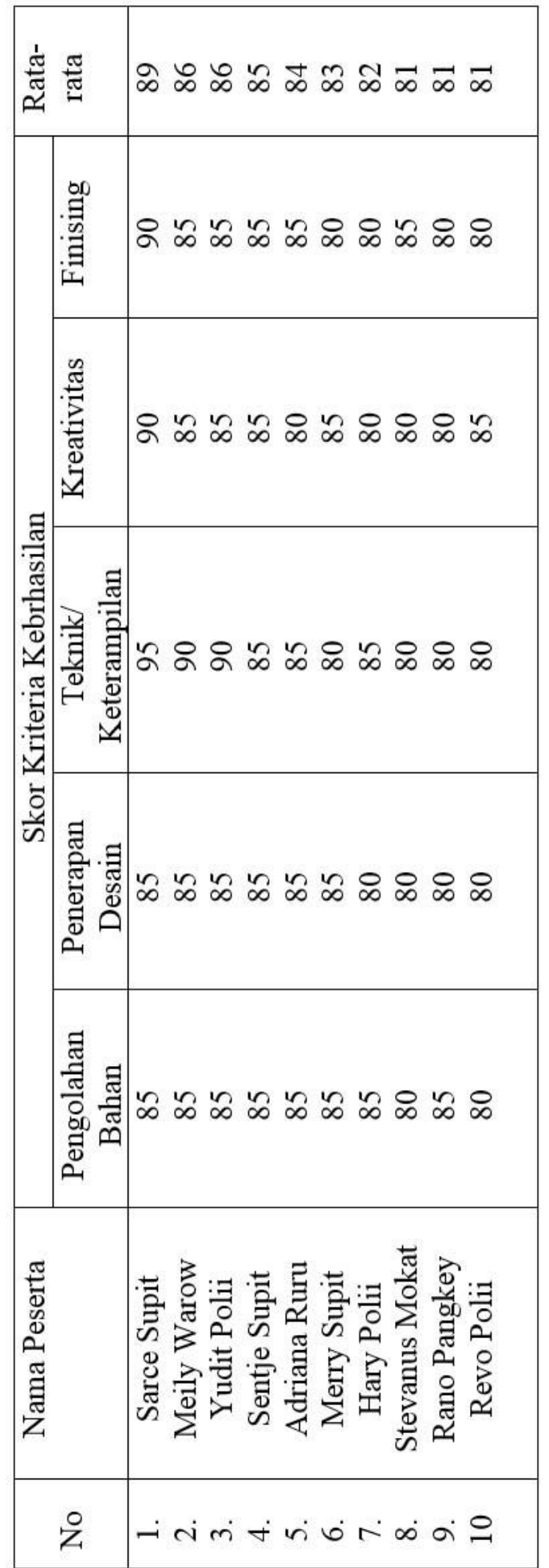

Catatan:

1. Hasil evaluasi berdasarkan table data indicator keberhasilan, menunjukkan 100\% mencapai skor diatas standar karena jumlah skor keberhasilan dari 10 peserta $=838$. Jadi nilai rata - rata keberhasilan seluruh peserta
$=838: 10=83,8(83,8 \%)$, dengan predikat baik (sangat memuaskan).

2. Dokumen kerajinan anyaman eceng gondok hasil pelatihan berbasis IPTEKS tampak pada gambar - gambar berikut ini :

Produk Kerajinan Anyaman Eceng Gondok Berbasis IPTEKS

(Kary a Peserta Pelatihan Berbasis IPTEKS di Desa Watumea Tondano)

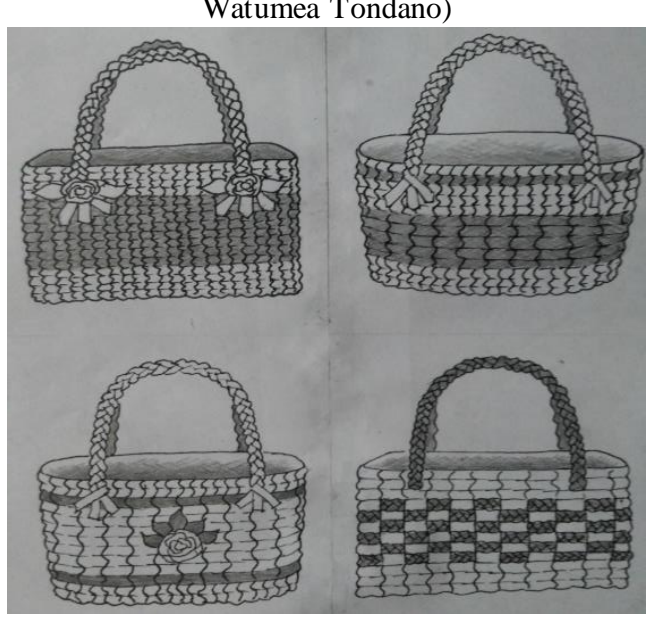

Desain Yang Ditawarkan
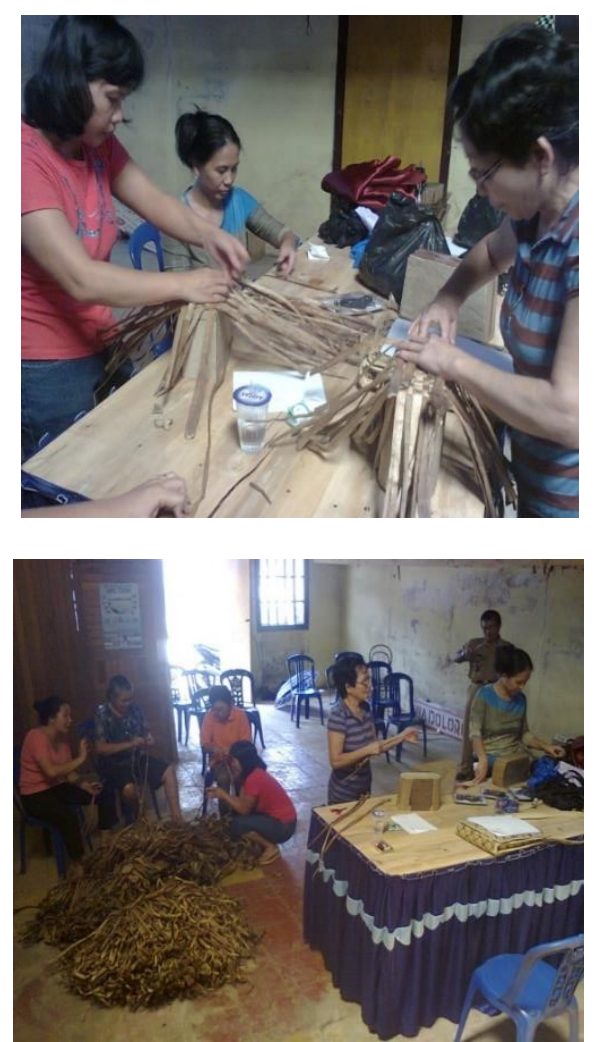


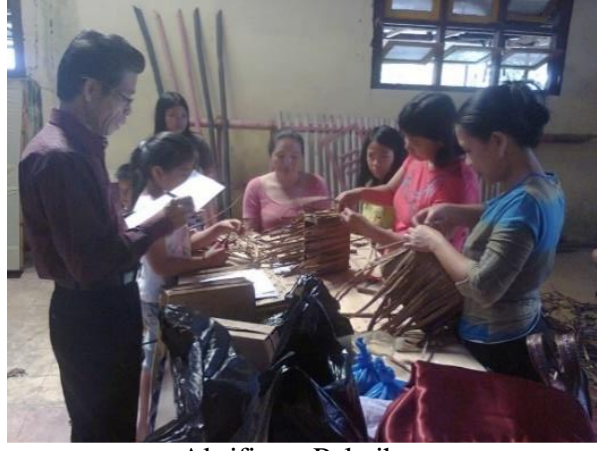

Aktifitas Pelatihan
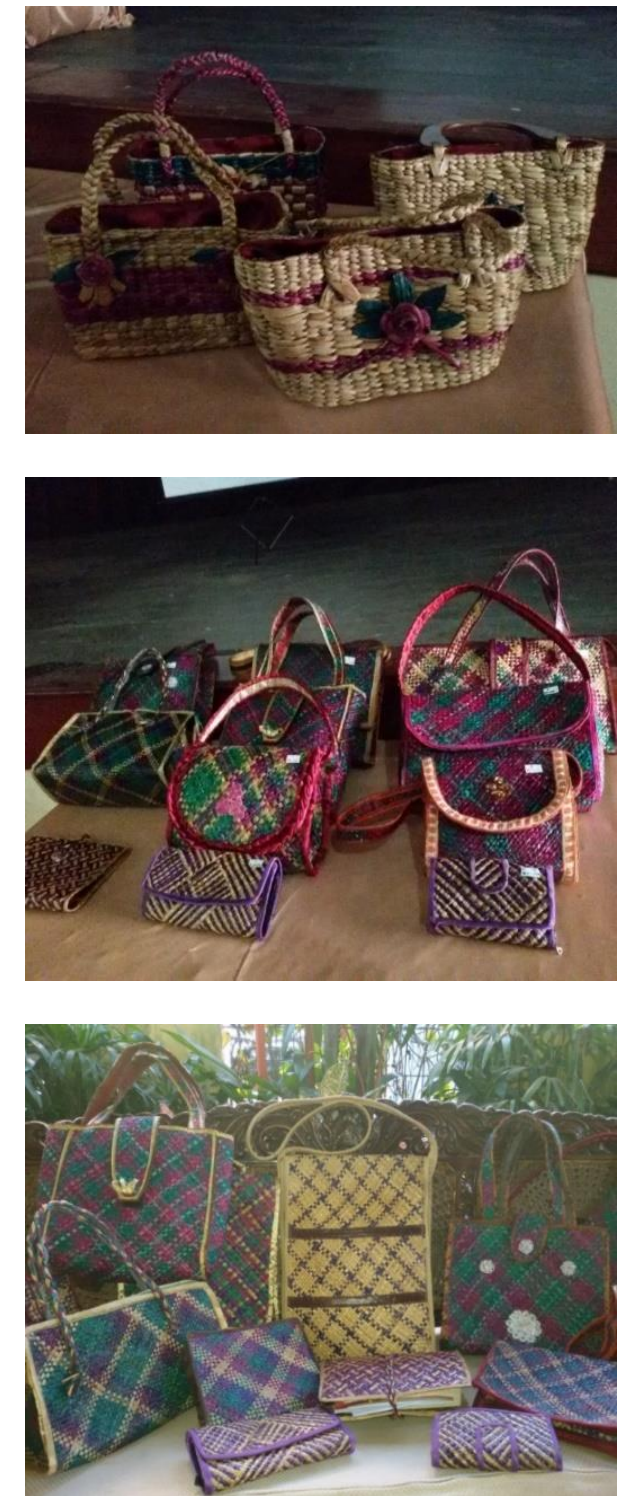

Produk Kerajinan Anyaman Eceng Gondok Hasil Pelatihan

\section{Pembahasan}

Sebelum pendekatan program pelatihan, kelompok pengrajin anyaman eceng gondok di Desa Watumea Tondano belum mampu memproduksi kerajinan anyaman secara teknologi industrial, selain produk yang dihasilkan cenderung mereproduksi produk kerajinan anyaman yang sederhana, baik untuk jenis tas maupun dompet sehingga kualitas produk tidak bersaing, karena produk luar relatif lebih berkualitas.

Disini menunjukkan masih rendahnya kemampuan dan kreativitas mendesain jenis jenis produk kerajinan anyaman eceng gondok yang lebih inovatif, menyebabkan daya produksi rendah yang berdampak pada daya jual (nilai jual) yang rendah. Hal ini menjadi salah satu kendala sehingga produktivitas pengrajin rendah yang turut mempengaruhi kesenjangan ekonomi di kalangan pengrajin. Karenanya sebagian besar pengrajin cenderung berprofesi ganda sebagai petani (berkebun) atau kerja serabutan.

Setelah program pelatihan berbasis IPTEKS yang dilaksanakan secara continue selama 4 hari (diluar waktu sosialisasi dan pendampingan pasca pelatihan), para peserta mitra yang telah menerima fasilitas (bahan dan peralatan) disertai pelatihan teknis secara tersistem dan terstruktur, termotivasi/ tertantang untuk berproduksi secara profesional serta menjadikan kerajinan anyaman eceng gondok sebaga profesi andalan/ utama. Terlebih saat program pelatihan kerajinan anyaman eceng gondok selesai, sejumlah karya hasil pelatihan disajikan dalam Pameran Pembangun Kabupaten Minahasa melalui stand Dinas Perindustrian dan Perdagangan Kabupaten dan semua produk berupa tas, dompet, tempat tisu habis terjual. Harga satuan tas laku terjual Rp. 100.000 sampai 150.000 , sedangkan harga satuan dompet terjual 25.000 sampai 50.000 rupiah. Hasil penjualannya diserahkan pada kelompok pengrajin anyaman eceng gondok desa Watumea Tondano.

Sebelum ada pelatihan berbasis IPTEKS, produk tas dan dompet yang dihasilkan hanya dihargai para pemesan (konsumen) Rp. 50.000 untuk satu buah tas dan untuk dompet tidak lebih dari Rp. 20.000. Hal inilah salah satu pemicu para pengrajin semakin bergairah/ termotivasi untuk mengembangkan dan menggeluti jenis profesi pengrajin anyaman eceng gondok ini, karena hasilnya benar-benar member nilai tambah ekonomi yang menyajikan. Didukung pula adanya bahan baku eceng gondok melimpah dan terbarukan serta 
sejumlah peralatan dan bahan-bahan pendukung yang telah difasilitasi dana PNBP Universitas Negeri Manado melalui program Pelatihan berbasis IPTEKS yang diselenggarakan Lembaga Pengabian Masyarakat UNIMA tahun 2015.

\section{KESIMPULAN}

Dalam laporan akhir pengabdian masyarakat berbasis IPTEKS pada kelompok pengrajin anyaman eceng gondok di Desa Watumea Tondano ini, dapat ditarik kesimpulan :

a. Kehadiran program hibah pengabdian masyarakat melalui pelatihan keterampilan berbasis IPTEKS ini benar-benar sangat menunjang produktivitas, profesionalitas serta kesinambungan usaha industrikerajinan di tengah masyarakat pengrajin anyaman eceng gondok.

b. Pelatihan keterampilan berbasis IPTEKS pada kelompok pengrajin anyaman eceng gondok di Desa Watume dipastikan dapat meningkatkan pendapatan ekonomi pasca pelatihan.

c. Sinerjitas para pengrajin dan pemerintah serta instansi terkait akan berdampak pada peningkatkan kualitas hidup masyarakat pengrajin sekaligus dapat meningkatkan pendapatan asli daerah lewat pariwisata dan ekonomi kerakyatan.

\section{Saran}

a. Program pengabdian masyarakat berbasis IPTEKS dengan dana PNBP serta skema lainnya diharapkan akan tetap berlanjut.

b. Selain pendampingan teknis pasca pelatihan, para peserta pelatihan perlu disisikan dana pendamping sebagai perangsang model untuk melanjutkan usaha produksi. Karenanya perlu dipertimbangkan peningkatan pagu dana pengabdian masyarakat berbasis IPTEKS menurut sifat dan urgensi sasaran pengabdian, agar dana yang dikeluarkan tidak mubasir.

c. Demi efektivitas dan obyektivitas pelaksana program pelatihan keterampilan di lokasi mitra masyarakat, diharapkan adanya monitoring dari staf/ pejabat LPM setempat di semua lokasi pelaksanaan program.

\section{REFERENSI}

Arasy-Hasan, 2012, Manfaat Tumbuhan Eceng Gondok. http://blogspot.com/manfaat-tumbuhan-ecenggondok.

Dalam KBBI, 1995, 531: Suatu Pekerjaan atau Kerajinan Tagan.

http://kadokado.indonetwork.or.id/88817/ke rajinan-enceng-gondok3.htm

dari revolusi industri di inggris pada abad 18 , "WILLIAM MORES dan "JOHN RUSKIN (INTERNET)

Fadholi, A. 2009. Kerajinan Enceng Gondok, (online).

http://ariffadholi.blogspot.com/2009/10/ker ajinan-enceng-gondok.html, diakses 9 Juni 2011

Forumbebas, 2013, Potensi Eceng Gondok.

Fratelo. 2010. Enceng Gondok. http://archive.kaskus.us/thread/3449869, TEKHNIK PENULISAN ILMIAH. Diakses 9 Juni 2011.

Galreriukm. 2010. Bisnis Kerajinan Enceng Gondok.

http://galeriukm.web.id/unitusaha/handicraft/bisnis-kerajinan-encenggondok, diakses 9 juni 2011

Gunarto Murtihadi, 1982. Dasar-Dasar Desain (untuk SMIK), Depdikbud, Jakarta

Gustami S. P, 2007. Butir-Butir Mutiara Estetika Timur (Ide Desain Penciptaan Seni Kriya Indonesia), Prasista, Jogyakarta.

Mela, 2009, Enceng Gondok Sebagai Kerajinan.

http://umm.ac.id/eceng-gondok-sebagaikerajinan.

Ir. Anton Gerbono, Ir. Abbas Siregar Djarijah. Kerajinan Eceng Gondok. Yogyakarta

Kompasiana. 2012. Eceng Gondok Mengubah Beban Menjadi Manfaat. http://green.com/potensi/2012/10/22/ecenggondok.

Prof. Darji Darmodiharjo, SH. Penuntun Praktek Kerajinan

Lies Suprapti. 2000. Kerajinan Enceng Gondok Trubus Agrisarana, Surabaya.

Moleong, Lexi Y 2000. Metodologi Kualitatif, PT.

Remajarosdakarya, Bandung

Rasjoyo, Seni Kria Adalah Karya Pertama (Sample), (INTERNET)

Wikipedia. 2010. Eceng Gondok. http://id.wikipedia.org/wiki/eceng gondok. TEKNIK PENULISAN ILMIAH. Diakses 9 Juni 2011 